\title{
The role of mannose-binding lectin gene polymorphisms in susceptibility to HIV-1 infection in Southern Brazilian patients
}

\author{
Gabriela Kniphoff da Silva ${ }^{a, *}$, Rafael Guimarães ${ }^{b, *}$, \\ Vanessa Suñé Mattevic ${ }^{\mathrm{c}}$, Rosmeri Kuhmmer Lazzarettid, \\ Eduardo Sprinz ${ }^{d}$, Regina Kuhmmer ${ }^{d}$, Lucas Brandão ${ }^{b}$, \\ Sérgio Crovellab and José Artur Bogo Chies ${ }^{a}$
}

Objective: This study investigates the role of mannose-binding lectin (MBL) in the susceptibility to HIV-1 infection analyzing polymorphisms located at the MBL2 promoter and exon 1 regions.

Materials and methods: The prevalence of $M B L 2$ variant alleles was investigated in 410 HIV-1-infected patients from the South Brazilian HIV cohort and in 345 unexposed uninfected healthy individuals. The promoter variants were genotyped using polymerase chain reaction with sequence-specific primers (PCR-SSP) and exon 1 variants were analyzed by real-time PCR using a melting temperature assay and were confirmed by PCR-restriction fragment length polymorphism (RFLP). MBL2 genotypic and allelic frequencies were compared between HIV-1-infected patients and controls using the chi-squared tests.

Results: The analyses were performed subdividing the individuals according to their ethnic origin. Among Euro-derived individuals a higher frequency of the LX/LX genotype was observed in patients when compared to controls $(P<0.001)$. The haplotypic analysis also showed a higher frequency of the haplotypes associated with lower MBL levels among HIV-1-infected patients $(P=0.0001)$. Among Afro-derived individuals the frequencies of LY/LY and $\mathrm{HY} / \mathrm{HY}$ genotypes were higher in patients when compared to controls ( $P=0.009$ and $P=0.02)$.

Conclusions: An increased frequency of $M B L 2$ genotypes associated with low $M B L$ levels was observed in Euro-derived patients, suggesting a potential role for MBL in the susceptibility to HIV-1 infection in Euro-derived individuals.

(c) 2011 Wolters Kluwer Health | Lippincott Williams \& Wilkins

AIDS 2011, 25:411-418

Keywords: ethnicity, HIV, immunogenetics, MBL, polymorphisms

\section{Introduction}

The acquired immune deficiency syndrome (AIDS) became known worldwide in the 1980s, when the first epidemic signals appeared. Without treatment, life expectancy of patients diagnosed with AIDS is around 2 years $[1,2]$. Interestingly, humans show a remarkable variation in vulnerability to HIV infection, probably due to genetic and immunologic factors. HIV transmission depends on infectivity factors (for example, the higher the

\footnotetext{
a Universidade Federal do Rio Grande do Sul, ${ }^{\mathrm{b}}$ Universidade Federal de Pernambuco, ${ }^{\mathrm{C}}$ Universidade Federal de Ciências da Saúde de Porto Alegre, and ${ }^{\mathrm{d}}$ Hospital de Clínicas de Porto Alegre, Porto Alegre, Brazil.

Correspondence to Dr José Artur Bogo Chies, Laboratory of Immunogenetics, Institute of Biosciencies, Department of Genetics, UFRGS, Av. Bento Gonçalves - 9500, PO BOX 15053, Campus do Vale 91501970, Porto Alegre, RS, Brazil.

Tel: +55 513308 6740; fax: +55 513308 7311; e-mail: jabchies@terra.com.br

${ }^{*}$ G.K.daS. and R.G. contributed equally to the writing of the article.

Received: 28 May 2010; revised: 11 November 2010; accepted: 22 November 2010.
} 
viral load, the greater the chance of transmission) as well as on host susceptibility [3].

There are two distinct HIV types, HIV-1 and HIV-2, though in Brazil HIV-1 is much more prevalent than HIV-2 [4,5]. Infectivity depends on HIV-1 concentration and presence and number of cells infected with the virus in body fluids, although the viral and cell requirements for HIV-1 transmission remain poorly understood [5]. By 2008, there were 33.4 million people living with HIV worldwide. In that year, 2.7 million new cases were reported and 2 million died from the disease worldwide [6]. In Brazil, by 2009 approximately 544 thousand cases of the disease had been reported, since the first case in 1980 [2]. The resistance to infection reflects the combination of genetic factors, innate and acquired immuno-resistance. Among the genetic factors associated with HIV resistance, homozygosis of the delta 32 allele of the CCR 5 gene is the best known [5].

In recent years, there has been an emerging interest in mannose-binding lectin (MBL) due to its central role as a recognition molecule in the complement system. MBL is a member of a family of proteins called collectins and is characterized by the presence of both a collagenous region and a lectin domain $[7,8]$. This protein is produced by the liver and is capable of binding mannan, gramnegative bacteria and envelope glycoproteins of viruses [9]. After binding to a pathogen, MBL goes through a conformational change and activates associated molecules, such as MBL-associated serine proteases (MASP-1, MASP-2 and MASP-3), resulting in complement activation by the lectin pathway [10,11]. Since HIV gp120 protein is highly glicosylated, it has been suggested that MBL could be involved in HIV-1 binding and opsonization [12].

Mannose-binding lectin is also known as a paradox of innate immunity. High MBL serum levels are useful in the immune response against extracellular pathogens. MBL recognizes pathogens and triggers phagocytosis, opsonization and elimination of the microorganism. Conversely, MBL-facilitated opsonization and phagocytosis may increase the infectivity of some intracellular pathogens. Thus, it could be said that, in the case of intracellular pathogens, low MBL levels offer an advantage to the host by hindering the infection [9,12-14]. The human mannose-binding lectin gene $(M B L 2)$ is located on chromosome 10 (q11.2-q21) and contains four exons. Polymorphisms located at exon 1 are reported to interfere with protein conformation, resulting in altered collagenous regions and, as a consequence, inhibiting oligomerization. This leads to low serum MBL levels and impaired protein function $[12,15,16]$. MBL2 gene exon 1 region contains three functional single-nucleotide polymorphisms (SNPs), at codon 52 (CGT to TGT, Arg $\rightarrow$ Cys, referred as ' $\mathrm{D}$ ' allele), at codon 54 (GGC to GAC, Gly $\rightarrow$ Asp, 'B' allele) and at codon 57 (GGA to GAA,
Gly $\rightarrow$ Glu, 'C' allele). A wild-type sequence is called allele ' $A$ ', and the presence of any of these variants is defined as allele ' 0 ' $[17,18]$. Additional polymorphisms in the promoter and $5^{\prime} \mathrm{UTR}$ regions of the $M B L 2$ are also associated to reduced serum MBL levels [19]. The H/L polymorphism is located at $-550 \mathrm{bp}, \mathrm{X} / \mathrm{Y}$ is found at $-221 \mathrm{bp}$ (both are $\mathrm{G}$ to $\mathrm{C}$ nucleotide substitutions), and $\mathrm{P} / \mathrm{Q}$ is located at position +4 of the $5^{\prime} \mathrm{UTR}(\mathrm{C} / \mathrm{T})$. These three polymorphisms are in strong linkage disequilibrium with exon 1 SNPs, and seven more common haplotypes have been described: HYPA, LYQA, LYPA, LXPA, LYPB, LYQC and HYPD [7,20-22].

Several mechanisms associate MBL to HIV infection. MBL can promote activation of inflammatory cells and, by doing so, induce the depletion of $\mathrm{T} \mathrm{CD} 4^{+}$cells [23]. It has been shown that HIV-infected patients carrying MBL2 mutations had a significantly shorter lifespan after AIDS diagnosis [24]. Heggelund et al. [25] suggested that MBL can increase HIV replication, inducing persistent inflammatory response. Also, the 'B' allele was associated with disease progression, and two studies found association of exon 1 genotypes with HIV vertical transmission [26-28]. Although the mechanism of MBL-HIV interaction has not as yet been fully understood, most studies suggest that MBL deficiency is a risk factor for HIV infection. However, these findings were not replicated in all populations analyzed, and some studies do not evidence a role for $\mathrm{MBL}$ in the susceptibility to HIV infection $[9,23]$. In our study we genotyped 410 HIV-positive patients and 345 healthy blood donors, both from Southern Brazil, looking for a possible association between $M B L 2$ polymorphisms and HIV infection.

\section{Materials and methods}

\section{Patients and controls}

HIV-infected patients were consecutively enrolled at the South Brazilian HIV cohort (SOBRHIV) from January 2004 through November 2005, in Porto Alegre, capital of Brazil's southernmost state [29]. The inclusion criteria were as follows: asymptomatic HIV-infected individuals on highly active antiretroviral therapy (HAART) for at least 1 year (HAART prescribed according to Brazilian guidelines at that time) [2]; HIV-1 RNA load less than 50 copies $/ \mathrm{ml}$ determined by the technical Versant HIV-1 RNA 3.0 assay/bDNA automation system in 340 bDNA Analyzer (Bayer, Germany); and over 18 years of age. Exclusion criteria were: pregnancy, current use of drugs that could be associated to body changes such as corticosteroids or anabolizing steroids, and mental illness. Written informed consent was signed by all individuals and the protocol was approved by the Hospital de Clínicas de Porto Alegre Ethics Research Committee. 
Table 1. Demographic characteristics of the study group.

\begin{tabular}{lll}
\hline Characteristics & HIV-infected individuals $(n=410)$ & Control group $(n=345)$ \\
\hline Sex (male/females) & $224 / 186$ & $243 / 102$ \\
Age (years \pm SD and min-max) & $42.98 \pm 9.42(19-73)$ & $43.43 \pm 7.78(20-62)$ \\
Ethnicity (European/African-derived) & $239 / 171$ & $244 / 101$ \\
HCV co-infection $(n, \%)$ & $103(25.1 \%)$ & $\mathrm{NA}$ \\
HBV co-infection $(n, \%)$ & $17(4.1 \%)$ & $\mathrm{NA}$ \\
\hline
\end{tabular}

NA, not apply.

A total of 410 samples from HIV-infected individuals, 224 men and 186 women, with ages ranging from 19 to 73 years were obtained. Patients were classified as European or African-derived according to phenotypic characteristics of individuals and ethnicity data of parents/ grandparents reported by the participants in an appropriate questionnaire. The issue concerning skin colorbased classification criteria adopted in Brazil is well documented and has been already assessed by our group in previous studies [30,31]. In total, 239 individuals were classified as European-derived and 171 were classified as African-derived.

The control group was formed by 345 unexposed, uninfected healthy blood donors, 244 being Europeanderived and 101 African-derived, from the urban population of Porto Alegre, the capital of the southernmost state of Brazil. The demographic characteristics of both groups are described in Table 1. All patients and controls participating in this study gave their written informed consent. The genomic DNA for molecular characterization was obtained from $5-\mathrm{ml}$ peripheral blood samples collected with ethylenediaminetetraacetic acid (EDTA) and purified through a salting-out procedure as described by Lahiri and Nurnberger [32].

\section{Exon 1 genotyping}

MBL2 exon 1 polymorphisms genotyping was performed by melting temperature assay following the protocol of Arraes et al. [27]. After melting temperature genotyping, $\mathrm{A} / 0$ and $0 / 0$ genotypes were confirmed by polymerase chain reaction-restriction fragment length polymorphism (PCR-RFLP) assay [33], and the specific presence of 'B', 'C' and 'D' alleles was defined.

\section{Promoter region genotyping}

The promoter region of the MBL2 gene spanning the $550(\mathrm{~L}$ or $\mathrm{H}$ ) and -221 (X or $\mathrm{Y}$ ) polymorphisms was amplified by PCR with sequence-specific primers (PCR-SSP) as described by Neonato et al. [34], using specific primers named: $\mathrm{L}$ forward, $\mathrm{X}$ reverse, $\mathrm{H}$ forward and $\mathrm{Y}$ reverse. Four simultaneous reactions were performed for each sample, using different combinations of primers (LX, LY, HX and HY), to identify the haplotypes. The amplified fragments were visualized in $2 \%$ agarose gels. In addition, a control gene (cytochrome $\mathrm{P} 450$ debrisoquine, CYP2D6) was amplified in all the reactions.

\section{Statistical analysis}

MBL2 genotypic distribution was determined by direct counting. The genotypic frequencies were compared to Hardy-Weinberg expectations using chi-squared tests. MBL2 allelic frequencies were compared between patients and controls using the chi-squared test and adjusted residuals were also calculated. The significance level was set as $\alpha=0.05$ (two-tailed). All statistical analyses were performed with SPSS 15.0 (SPSS Inc., Chicago, Illinois, USA) and WinPepi 10.0 softwares.

\section{Results}

Data from the literature concerning $M B L 2$ polymorphic variant frequencies revealed a high level of interethnic diversity. For this reason, our analyses were performed subdividing the individuals according to ethnic origin [33,35]. The European-derived group included 244 healthy individuals and $239 \mathrm{HIV}$-positive patients. In this group, we first evaluated exon $1 \mathrm{MBL} 2$ polymorphisms (Table 2). The frequency of MBL2 0/0 homozygote genotype was 0.053 in controls and 0.042 in HIV-positive patients; no statistical difference was found. All A/0 and $0 /$ 0 individuals were then genotyped in order to identify ' $\mathrm{B}$ ', ' $C$ ' and ' $D$ ' alleles. The analyses of the allelic frequencies showed a higher frequency of the ' $\mathrm{D}$ ' allele in HIV-positive patients, when compared to controls $(P=0.002)$.

We also compared the frequency of $M B L 2$ promoter polymorphisms (Table 3). Among healthy individuals, 0.041 were genotyped as X/X against 0.122 of the HIVpositive patients $(P=0.001)$. The analysis of the haplotypes showed a higher frequency of the LY haplotype in the control group, when compared to HIV-infected patients $(P=0.048)$. The haplotypic combination frequencies were also compared between cases and controls, showing a higher frequency of the LX/LX genotype in the HIVinfected patients when compared to healthy individuals (0.122 and 0.041, respectively; $P=0.001$ ).

Finally, we grouped MBL2 exon 1 and promoter genotypes and calculated combined genotypes classifying them in three classes, associated with MBL serum levels (as described in the literature): high serum MBL levels (HYA/A and LYA/A), intermediate serum MBL levels (LXA/LXA, HYA/0 and LYA/0) and deficient serum MBL levels (LXA/0 and 0/0) [12]. MBL2 combined 
Table 2. Distribution of $M B L 2$ exon 1 polymorphisms allelic and genotypic frequencies in HIV-1-infected individuals and controls, according to ethnicity.

\begin{tabular}{|c|c|c|c|c|}
\hline \multirow[b]{2}{*}{ Genotypes } & \multicolumn{2}{|c|}{ European-derived } & \multicolumn{2}{|c|}{ African-derived } \\
\hline & $\begin{array}{c}\text { Control freq }(n) \\
\quad n=244\end{array}$ & $\begin{array}{c}\text { HIV + freq }(n) \\
n=239\end{array}$ & $\begin{array}{c}\text { Control freq }(n) \\
\quad n=101\end{array}$ & $\begin{array}{c}\text { HIV+ freq }(n) \\
n=171\end{array}$ \\
\hline $\mathrm{A} / \mathrm{A}$ & $0.607(148)$ & $0.544(130)$ & $0.584(59)$ & $0.526(90)$ \\
\hline $\mathrm{A} / 0$ & $0.340(83)$ & $0.414(99)$ & $0.366(37)$ & $0.409(70)$ \\
\hline \multirow[t]{2}{*}{$0 / 0$} & $\begin{array}{l}0.053(13) \\
\chi^{2}, P=0.233\end{array}$ & $0.042(10)$ & $\begin{array}{l}0.050(5) \\
\chi^{2}, P=0.630\end{array}$ & $0.064(11)$ \\
\hline & $n=244$ & $n=229$ & $n=101$ & $n=167$ \\
\hline $\mathrm{A} / \mathrm{A}$ & $0.607(148)$ & $0.568(130)$ & 0.584 (59) & $0.539(90)$ \\
\hline \multicolumn{5}{|l|}{$\mathrm{A} / 0$} \\
\hline $\mathrm{A} / \mathrm{B}$ & $0.246(60)$ & $0.223(51)$ & $0.099(10)$ & $0.192(32)$ \\
\hline $\mathrm{A} / \mathrm{C}$ & $0.037(9)$ & $0.039(9)$ & $0.218(22)$ & $0.132(22)$ \\
\hline $\mathrm{A} / \mathrm{D}$ & $0.057(14)$ & $0.127(29)$ & $0.050(5)$ & $0.072(12)$ \\
\hline \multicolumn{5}{|l|}{$0 / 0$} \\
\hline $\mathrm{B} / \mathrm{C}$ & $0.020(5)$ & $0.000(0)$ & $0.010(1)$ & $0.006(1)$ \\
\hline $\mathrm{B} / \mathrm{D}$ & $0.008(2)$ & $0.018(4)$ & $0.000(0)$ & $0.018(3)$ \\
\hline$C / D$ & $0.000(0)$ & $0.004(1)$ & $0.000(0)$ & $0.012(2)$ \\
\hline $\mathrm{B} / \mathrm{B}$ & $0.025(6)$ & $0.013(3)$ & $0.010(1)$ & $0.030(5)$ \\
\hline $\mathrm{C} / \mathrm{C}$ & $0.000(0)$ & $0.004(1)$ & $0.030(3)$ & $0.000(0)$ \\
\hline $\mathrm{D} / \mathrm{D}$ & $0.000(0)$ & $0.004(1)$ & $0.000(0)$ & $0.000(0)$ \\
\hline \multicolumn{5}{|c|}{ No statistical comparison was performed on these data due to the small number of individuals in each subgroup } \\
\hline Alleles & $n=488$ & $n=468$ & $n=202$ & $n=334$ \\
\hline A & $0.777(379)$ & 0.767 (359) & $0.767(155)$ & $0.736(246)$ \\
\hline B & $0.162(79)$ & $0.130(61)$ & $0.065(13)^{b}$ & $0.138(46)^{b}$ \\
\hline $\mathrm{C}$ & $0.029(14)$ & $0.026(12)$ & $0.144(29)^{\mathrm{c}}$ & $0.075(25)^{\mathrm{c}}$ \\
\hline \multirow[t]{2}{*}{$\mathrm{D}$} & $0.033(16)^{\mathrm{a}}$ & $0.077(36)^{\mathrm{a}}$ & $0.025(5)$ & $0.051(17)$ \\
\hline & $\chi^{2}, P=0.016$ & & $\chi^{2}, P=0.003$ & \\
\hline
\end{tabular}

0 allele $=B+C+D$ alleles; $A$ allele $=$ wild type; $\mathrm{A} / \mathrm{A}$ genotype, high serum $\mathrm{MBL}$ levels; $\mathrm{A} / 0$ genotype, Intermediate serum $\mathrm{MBL}$ levels; $0 / 0$ genotype, lower serum MBL levels.

${ }^{2}$ Adjusted residual, $P=0.003$.

${ }^{\mathrm{b}}$ Adjusted residual, $P=0.009$.

${ }^{\mathrm{c}}$ Adjusted residual, $P=0.01$.

genotypes are shown in Table 4. The frequency of genotypes associated with high serum MBL levels was 0.574 in healthy individuals and 0.460 in HIV-positive patients $(P=0.012)$. Conversely, frequency of genotypes associated with lower serum MBL levels was 0.053 in healthy individuals and 0.174 in HIV-positive patients $(P<0.0001)$.

The same approach was used to analyze the Africanderived individuals (101 healthy individuals and 171 HIVpositive patients). Both patients and controls showed a similar distribution of MBL2 exon 1 polymorphisms (grouped as allele ' $A$ ' and allele ' $O$ ') (Table 2). When the analysis was conducted using 'B', 'C' and 'D' alleles separately, we observed an increased frequency of ' $\mathrm{B}$ ' allele in patients $(0.138)$ with respect to the controls $(0.065$; $P=0.009)$. Conversely, an increased frequency of ' $\mathrm{C}$ ' allele was detected in controls in comparison to patients $(0.144$ and 0.075 , respectively; $P=0.01$ ) (Table 2 ).

Concerning the MBL2 promoter region, a higher frequency of the LY/LY haplotypic combination was observed among healthy individuals (0.390), compared with HIV-positive patients $(0.158 ; P<0.001)$; also, an increase in the $\mathrm{LY} / \mathrm{HY}$ and $\mathrm{HY} / \mathrm{HY}$ genotypes in patients
(0.316 and 0.164 , respectively) was observed in comparison with controls ( 0.18 and 0.07 , respectively) $(P=0.015$ and $P=0.026$, in that order). These findings reflected $M B L 2$ haplotypic frequencies [see, for example, a frequency of 0.60 of the LY haplotype in the controls against 0.39 in HIV-positive patients $(P<0.001)$, and the frequency of 0.37 of the HY haplotype in patients, compared with 0.19 in controls $(P<0.001)]$. When genotypes were examined, $\mathrm{H} / \mathrm{L}$ and $\mathrm{H} / \mathrm{H}$ were more frequent in HIV-positive individuals (0.42 and 0.16), compared to 0.24 and 0.07 in healthy individuals $(P=0.003$ and $P=0.026)$, whereas the $\mathrm{L} / \mathrm{L}$ genotype had a frequency of 0.69 among controls and 0.41 in patients $(P<0.0001)$ (Table 3$)$. When $M B L 2$ exon 1 and promoter polymorphisms were grouped and combined genotypes analyzed, no statistically significant differences were observed.

We also performed analysis subdividing HIV-infected individuals according to co-infection with hepatitis $\mathrm{B}$ and $\mathrm{C}$, considering that these infections have similar routes of transmission, making co-infection a common event. In the group of HIV-infected individuals, 17 patients were co-infected with hepatitis B virus (0.04) and 103 were co-infected with hepatitis $C$ virus (0.25). Yet, we did not find statistical differences (data not shown). 
Table 3. MBL2 promoter polymorphisms frequencies in patients and controls, according to ethnicity.

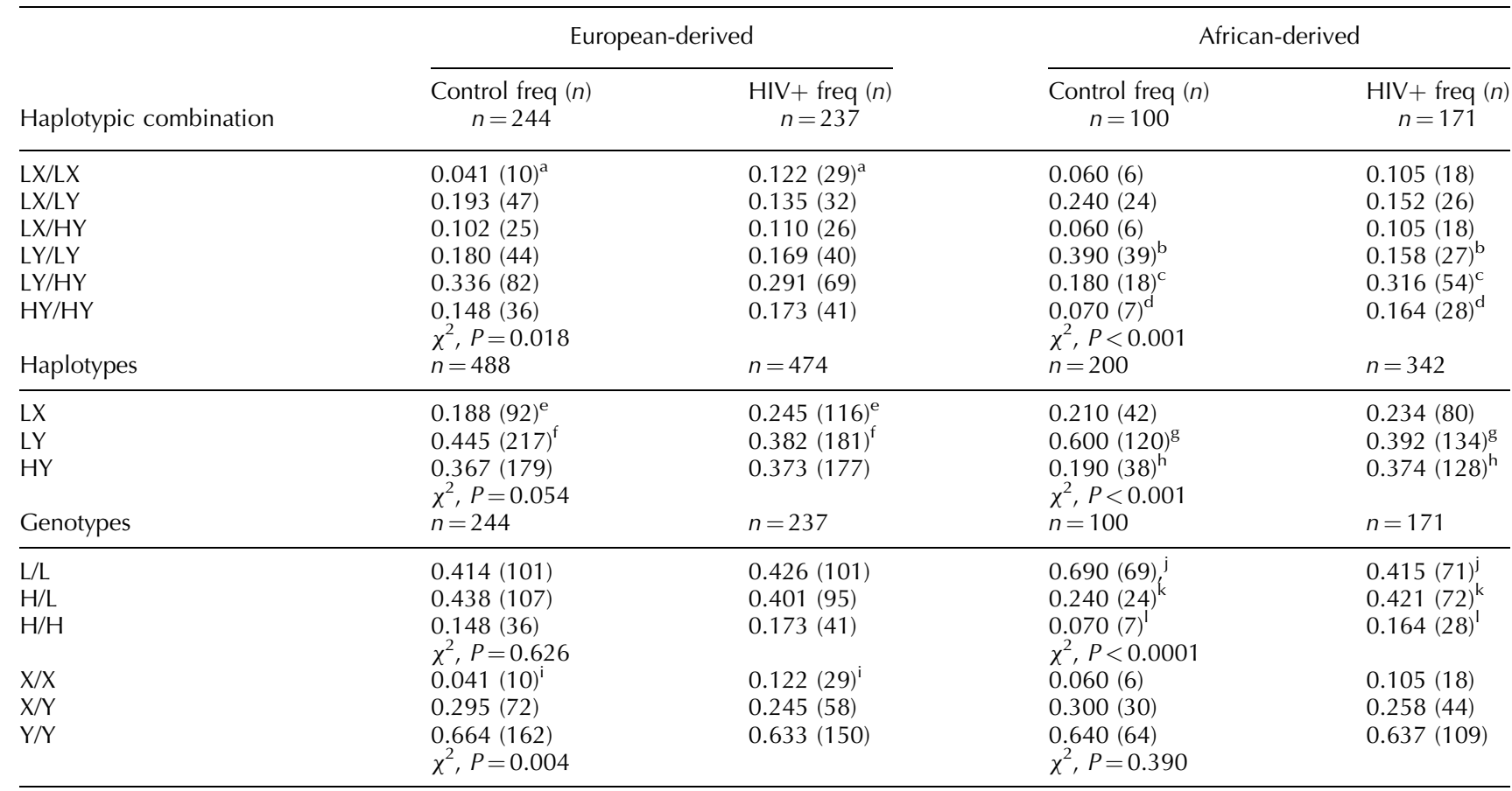

HY haplotype, high serum MBL levels; LX haplotype, lower serum MBL levels; LY haplotype, intermediate serum MBL levels.

${ }^{a}$ Adjusted residual, $\chi^{2}, P=0.001$.

${ }^{\mathrm{b}}$ Adjusted residual, $\chi^{2}, P<0.001$.

${ }^{\mathrm{c}}$ Adjusted residual, $\chi^{2}, P=0.015$.

${ }^{\mathrm{d}}$ Adjusted residual, $\chi^{2}, P=0.026$.

eAdjusted residual, $\chi^{2}, P=0.034$.

${ }^{\mathrm{f}}$ Adjusted residual, $\chi^{2}, P=0.048$.

${ }^{g}$ Adjusted residual, $\chi^{2}, P<0.001$.

${ }^{\mathrm{h}}$ Adjusted residual, $\chi^{2}, P<0.001$.

iAdjusted residual, $\chi^{2}, P=0.001$.

'Adjusted residual, $\chi^{2}, P<0.0001$.

${ }^{k}$ Adjusted residual, $\chi^{2}, P=0.003$.

'Adjusted residual, $\chi^{2}, P=0.026$.

\section{Discussion}

Mannose-binding lectin is an important molecule in the first-line defense of the organism, and considering its ability to bind to HIV-1 gp120 glycoprotein, several studies have evaluated functional MBL2 polymorphisms in different populations in the context of HIV infection, although the conclusions were somewhat conflicting [37-39].
In the present study, we investigated the association between MBL2 gene polymorphisms and the susceptibility to HIV infection in patients and ethnicity-matched controls from Southern Brazil subdividing the individuals according to their ethnic origin [40].

Among European-derived individuals we observed a higher frequency of the ' $\mathrm{D}$ ' allele in HIV-positive patients when compared to the controls. Nevertheless,

Table 4. MBL2 combined genotypes related to MBL serum levels in HIV-1 patients and healthy controls, according to ethnicity.

\begin{tabular}{lllll}
\hline & \multicolumn{2}{c}{ Euro-descendant } & \multicolumn{2}{c}{ Afro-descendant } \\
\cline { 2 - 3 } & Control Freq $(n)$ & HIV + Freq $(n)$ & & Control Freq $(n)$ \\
\hline Combined genotypes & $n=244$ & $n=235$ & $n=100$ & $n=167$ \\
High & $0.574(140)^{\mathrm{a}}$ & $0.460(108)^{\mathrm{a}}$ & $0.540(54)$ & $0.443(74)$ \\
Intermediate & $0.373(91)$ & $0.366(86)$ & $0.290(29)$ & $0.395(66)$ \\
Deficient & $0.053(13)^{\mathrm{b}}$ & $0.174(41)^{\mathrm{b}}$ & $0.170(17)$ & $0.162(27)$ \\
& $\chi^{2}, P<0.0001$ & & $\chi^{2}, P=0.202$ & \\
\hline
\end{tabular}

Combined genotypes: High serum MBL levels (LYA/A, HYA/A); Intermediate serum MBL levels (LXA/LXA, LYA/0, HYA/0); Deficient serum MBL levels (LXA/0, 0/0).

${ }^{a}$ Adjusted residual, $P=0.012$.

${ }^{\mathrm{b}}$ Adjusted residual, $P<0.0001$. 
considering 'B', 'C' and ' $\mathrm{D}$ ' alleles grouped under the designation of ' 0 ' allele, similar frequencies were observed in patients and controls. Two independent studies, performed in Spanish and Colombian HIV-positive individuals, also reported the lack of association between MBL2 exon 1 polymorphisms and HIV infection [41,42]. Conversely different findings reporting an increased frequency of MBL2 0/0 genotype among HIV-positive individuals or the association with disease progression in children have been reported in different ethnic groups [27,43-47].

In spite of showing similar results to our study for the exon 1 polymorphisms, however, neither the study with Spanish patients nor the investigation in Colombian individuals analyzed the MBL2 promoter region polymorphisms. The analyses of the MBL2 promoter region polymorphisms in patients and ethnicity-matched controls from Southern Brazil showed an increased frequency of the LX/LX haplotypic combination in HIV-positive individuals (0.122) when compared to the healthy individuals (0.041), indicating a higher frequency of the genotype related with low MBL levels in HIVpositive patients. Promoter haplotypes and genotypes frequencies also suggested a tendency of increased frequency of LX haplotype and $\mathrm{X} / \mathrm{X}$ genotype in HIV-positive individuals with respect to the controls, indicating the increased presence of $\mathrm{X}$ allele, related to low serum MBL levels in patients. Taken together, these results suggest a possible role for these SNPs associated with low MBL levels, in HIV infection.

It is interesting to note that other studies also hypothesized a role of the X/X genotype in the context of HIV infection. For instance, the X/X genotype have already been correlated with a rapid rate of HIV infection progression [40], and homozygosity for the XA/XA genotype was proposed as an important genetic determinant of HIV-1 acquisition through vertical transmission [45].

Most studies with HIV patients did not analyze simultaneously exon 1 and promoter MBL2 polymorphisms known to be in linkage disequilibrium: the analysis of $M B L 2$ haplotypes and combined genotypes, known to be correlated with MBL levels, is able to provide more complete information about the role of MBL in the susceptibility to HIV infection. The exon 1 variants disturb protein polymerization, not only resulting in reduced serum MBL levels, but also functionally altering its ligand binding and complement activation capacities. The SNPs in the promoter region can modulate the serum concentration of the protein $[48,49]$. Therefore, MBL concentrations may vary considerably, due to a combination of structural and promoter gene polymorphisms.

When we considered together promoter and exon 1 gene polymorphisms a significant difference between HIVpositive patients and controls among European-derived individuals was found. The haplotypic combinations related to high MBL levels (LYA/A and HYA/A) were more frequent in controls (0.57) than in HIV-positive individuals (0.46), and the combined genotypes related with deficient MBL levels (LXA/0 and 0/0) were more frequent in HIV-positive patients (0.17) when compared to controls (0.05). Similar data were observed in a study performed with Hispanic individuals, when HIV-positive children, under 2 years of age, carrying MBL2 genetic variants resulting in lower MBL levels, were at a significantly greater risk of disease progression and central nervous system impairment when compared to the other patients tested [46]. Other studies found that HIV-positive pediatric patient carriers of the ' $\mathrm{B}$ ' allele and/or with low MBL levels progress more rapidly to AIDS. Also, adult HIV-positive patients with this pattern exhibit a significantly shorter survival time after an AIDS diagnosis $[44,50,51]$.

Among African-derived individuals, exon 1 polymorphisms (grouped as ' 0 ' allele) showed similar genotypic frequencies between patients and controls, although an increased frequency of the ' $\mathrm{B}$ ' allele was observed among patients and an increased frequency of the ' $\mathrm{C}$ ' allele was detected in controls. It is important to point out that the $M B L 2$ gene ' $\mathrm{C}$ ' allele is relatively frequent among individuals of African ancestry, which can explain the higher frequency observed among our controls [52,53]. Another study, in a South African population, observed that in the absence of intervention, infants with $M B L 2$ genetic variants were more likely to acquire HIV through vertical transmission than infants with the wild-type genotype [54].

The analyses of promoter polymorphisms showed an increased frequency of the $\mathrm{LY} / \mathrm{HY}$ and $\mathrm{HY} / \mathrm{HY}$ haplotypic combinations in patients, when compared to controls, as well as a lower frequency of LY/LY. The analysis of MBL2 haplotypes confirmed this higher frequency of the LY haplotype in controls, and of the HY haplotype in HIV-positive individuals. Since the LY haplotype is related to intermediate MBL serum levels and the HY haplotype is related with high MBL serum levels, the results indicate that African-derived patients have genotypes related to high MBL levels. Some studies with African-derived population suggested an association of MBL deficiency with resistance against leprosy and leishmaniasis $[55,56]$. The high prevalence of infections caused by intracellular pathogens in Africa may explain the differences in the MBL2 allelic frequency observed between European and African populations [53]. Two studies carried out with sub-Saharan and Indian populations showed that low MBL levels were related with susceptibility to HIV infection, but high levels of MBL may be involved in the pathogenesis of tuberculosis in these individuals, indicating that MBL may exert opposing effects, suggesting the need of a balance, modulated by different pathogens [51,57]. 
In the present study we considered only asymptomatic HIV-infected individuals that have been on HAART for 1 year, with HIV RNA less than 50 copies $/ \mathrm{ml}$. It is true that these criteria restrict the analyses to a specific group of patients, since MBL levels and/or variant alleles have been associated with progression of HIV disease in infected individuals, nevertheless, our study was aimed to detect the eventual association between MBL2 variants and the risk of being infected by HIV and no speculation about the role of MBL2 polymorphisms in the modification of the disease progression can be drawn with the study group analyzed.

Actually, we observed a marked difference in the distribution of MBL2 SNPs frequencies between European-derived and African-derived individuals. In European-derived individuals the majority of HIVpositive patients have genotypes related to low MBL serum levels. In African-derived individuals an opposite effect for MBL2 polymorphisms in the susceptibility to HIV infection has been observed. Genetic factors, other than $M B L 2$, reflecting the selection exercised by the exposure of the two ethnic groups to a different environment through time can explain these differences.

Finally, it has to be said that the ethnic classification used by our group (based on phenotypic characteristics of individuals and ethnicity data of parents/grandparents reported by the participants) is widely adopted in Brazil. However, we must admit that individuals classified as European-derived or African-derived can present a certain degree of admixture. A recent study by Santos et al. [36] assessed individual interethnic admixture using a 48-insertion-deletion Ancestry-Informative Marker panel. The authors identified a very high level of European contribution (94\%) and fewer Native American (5\%) and African (1\%) genes in a sample of 81 European-derived individuals from southern Brazil [36]. Therefore, the subgrouping of our HIV-infected patients and controls seems to reflect the actual ethnic/genetic background of this human population.

In conclusion, since low serum MBL concentrations are associated with inefficient phagocytosis and opsonization, our data suggest that MBL2 polymorphisms - and consequently low MBL levels - could lead to an inefficient response against viral infection in individuals with European ancestry. Thus, we suggest that individuals carrying $M B L 2$ variants being less efficient in the clearance of pathogens with mannose surface residues, such as HIV1, would be more susceptible to HIV-1 infection.

\section{Acknowledgements}

G.K.daS. and R.G. genotyped the patients, performed the experiments and wrote the manuscript. V.S.M. helped in the statistical analyses. R.K.L., E.S. and R.K. were responsible for clinical assistance. L.B. helped in genotyping. S.C. developed the genotyping test. J.A.B.C. conceived and designed the experiments.

The work was funded by CNPq (Conselho Nacional de Desenvolvimento Cientifico e Tecnológico) 479438/ 2009-9. J.A.B.C. received a CNPq grant 302105/20085. G.K.daS. received a CNPq grant 564988/2008-1.

\section{References}

1. Mindel A, Tenant-Flowers M. ABC of AIDS: natural history and management of early HIV infection. Br Med / 2001; 322:1290_ 1293.

2. Ministério da Saúde. Available at: $<$ www.aids.gov.br $>$. Access Date: March 20th, 2010.

3. Fellay J, Shianna KV, Ge D, Colombo S, Ledergerber B, Weale $M$, et al. A whole-genome association study of major determinants for host control of HIV-1. Science 2007; 317:944947.

4. Apetrei C, Gautam R, Sumpter B, Carter AC, Gaufin T, Staprans $\mathrm{SI}$, et al. Virus subtype-specific features of natural simian immunodeficiency virus SIVsmm infection in sooty mangabeys. J Virol 2007; 81:7913-7923.

5. Cohen MS, Hellmann N, Levy JA, Decock K, Lange J. The spread, treatment, and prevention of HIV-1: evolution of a global pandemic. J Clin Invest 2008; 118:1244-1254.

6. UNAIDS/WHO. AIDS epidemic update: December 2007. Geneva: UNAIDS 2007.

7. Turner MW, Hamvas RM. Mannose-binding lectin: structure, function, genetics and disease associations. Rev Immunogenet 2000; 2:305-322.

8. Monticielo OA, Mucenic T, Xavier RM, Brenol JC, Chies JA. The role of mannose-binding lectin in systemic lupus erythematosus. Clin Rheumatol 2008; 27:413-419.

9. Worthley DL, Bardy PG, Mullighan CG. Mannose-binding lectin: biology and clinical implications. Intern Med / 2005; 35:548-555.

10. Ip WK, To YF, Cheng SK, Lau YL. Serum mannose-binding lectin levels and mbl2 gene polymorphisms in different age and gender groups of southern Chinese adults. Scand I Immunol 2004; 59:310-314.

11. Selander B, Martensson U, Weintraub A, Holmstrom E, Matsushita $M$, Thiel $S$, et al. Mannan-binding lectin activates $\mathrm{C} 3$ and the alternative complement pathway without involvement of C2. I Clin Invest 2006; 116:1425-1434.

12. Bouwman LH, Roep BO, Roos A. Mannose-binding lectin: clinical implications for infection, transplantation, and autoimmunity. Hum Immunol 2006; 67:247-256.

13. Ezekowitz RA. Role of the mannose-binding lectin in innate immunity. J Infect Dis 2003; 187 (Suppl 2):S335-S339.

14. Fiane AE, Ueland T, Simonsen S, Scott H, Endresen K, Gullestad $\mathrm{L}$, et al. Low mannose-binding lectin and increased complement activation correlate to allograft vasculopathy, ischaemia, and rejection after human heart transplantation. Eur Heart j 2005: 26:1660-1665.

15. Maury CP, Aittoniemi J, Tiitinen S, Laiho K, Kaarela K, Hurme $M$. Variant mannose-binding lectin 2 genotype is a risk factor for reactive systemic amyloidosis in rheumatoid arthritis. J Intern Med 2007; 262:466-469.

16. Thio CL, Mosbruger T, Astemborski J, Greer S, Kirk GD, O'Brien $\mathrm{SJ}$, et al. Mannose binding lectin genotypes influence recovery from hepatitis B virus infection. J Virol 2005; 79:91929196.

17. Muller S, Keil T, Gruber C, Zitnik SE, Lau S, Wahn U, et al. MBL2 variants in relation to common childhood infections and atopyrelated phenotypes in a large German birth cohort. Pediatr Allergy Immunol 2007; 18:665-670.

18. Wiertsema SP, Herpers BL, Veenhoven RH, Salimans MM, Ruven HJ, Sanders EA, et al. Functional polymorphisms in the mannan-binding lectin 2 gene: effect on MBL levels and otitis media. I Allergy Clin Immunol 2006; 117:13441350 . 
19. Madsen HO, Garred P, Thiel S, Kurtzhals JA, Lamm LU, Ryder $\mathrm{LP}$, et al. Interplay between promoter and structural gene variants control basal serum level of mannan-binding protein. J Immunol 1995; 155:3013-3020.

20. Madsen HO, Satz ML, Hogh B, Svejgaard A, Garred P. Different molecular events result in low protein levels of mannan-binding lectin in populations from southeast Africa and South America. / Immunol 1998; 161:3169-3175.

21. Parrella P, Seripa D, Matera MG, Rinaldi M, Signori E, Gravina $C$, et al. Lack of association between genetic variants in the mannose-binding lectin 2 (MBL2) gene and HPV infection. Eur J Epidemiol 2007; 22:159-162.

22. Wang X, Saito J, Tanino $Y$, Ishida T, Fujita T, Munakata M Mannose binding lectin gene polymorphisms and asthma. Clin Exp Allergy 2007; 37:1334-1339.

23. Dommett RM, Klein N, Turner MW. Mannose-binding lectin in innate immunity: past, present and future. Tissue Antigens 2006; 68:193-209.

24. Turner MW. The role of mannose-binding lectin in health and disease. Mol Immunol 2003; 40:423-429.

25. Heggelund L, Mollnes TE, Espevik T, Muller F, Kristiansen KI, Aukrust $\mathrm{P}$, et al. Modulatory effect of mannose-binding lectin on cytokine responses: possible roles in HIV infection. Eur J Clin Invest 2005; 35:765-770.

26. Vallinoto AC, Menezes-Costa MR, Alves AE, Machado LF, de Azevedo VN, Souza LL, et al. Mannose-binding lectin gene polymorphism and its impact on human immunodeficiency virus 1 infection. Mol Immunol 2006; 43:1358-1362.

27. Arraes LC, de Souza PR, Bruneska D, Castelo Filho A, Cavada Bde S, de Lima Filho JL, et al. A cost-effective melting temperature assay for the detection of single-nucleotide polymorphism in the MBL2 gene of HIV-1-infected children. Braz J Med Biol Res 2006; 39:719-723.

28. Boniotto M, Braida L, Pirulli D, Arraes L, Amoroso A, Crovella S. MBL2 polymorphisms are involved in HIV-1 infection in Brazilian perinatally infected children. AIDS 2003; 17:779780.

29. Dabis F, Balestre E, Braitstein P, Miotti P, Brinkhof WG, Schnei$\operatorname{der} M$, et al. Cohort profile: antiretroviral therapy in lower income countries (ART-LINC): international collaboration of treatment cohorts. Int / Epidemiol 2005; 34:979-986.

30. Vargas AE, Marrero AR, Salzano FM, Bortolini MC, Chies JA. Frequency of CCR5delta32 in Brazilian populations. Braz J Med Biol Res 2006; 39:321-325.

31. Veit TD, Cordero EA, Mucenic T, Monticielo OA, Brenol JC, Xavier RM, et al. Association of the HLA-G 14 bp polymorphism with systemic lupus erythematosus. Lupus 2009; 18:424-430.

32. Lahiri DK, Nurnberger JI Jr. A rapid nonenzymatic method for the preparation of HMW DNA from blood for RFLP studies. Nucleic Acids Res 1991; 19:5444.

33. Monticielo OA, Chies JA, Mucenic T, Rucatti GG, Junior JM, da Silva GK, et al. Mannose-binding lectin gene polymorphisms in Brazilian patients with systemic lupus erythematosus. Lupus 2010; 19:280-287.

34. Neonato MG, Lu CY, Guilloud-Bataille M, Lapoumeroulie C, Nabeel-Jassim H, Dabit D, et al. Genetic polymorphism of the mannose-binding protein gene in children with sickle cell disease: identification of three new variant alleles and relationship to infections. Eur J Hum Genet 1999; 7:679-686.

35. Vianna P, da Silva GK, Dos Santos BP, Bauer ME, Dalmaz CA Bandinelli $\mathrm{E}$, et al. Association between mannose-binding lectin gene polymorphisms and preeclampsia in Brazilian women. Am / Reprod Immunol 2010; 64:359-374.

36. Santos NP, Ribeiro-Rodrigues EM, Ribeiro-Dos-Santos AK, Pereira R, Gusmao L, Amorim A, et al. Assessing individual interethnic admixture and population substructure using a 48insertion-deletion (INSEL) ancestry-informative marker (AIM) panel. Hum Mutat 2010; 31:184-190.

37. Hart ML, Saifuddin M, Spear GT. Glycosylation inhibitors and neuraminidase enhance human immunodeficiency virus type 1 binding and neutralization by mannose-binding lectin. $/$ Gen Virol 2003; 84:353-360.

38. Hart ML, Saifuddin M, Uemura K, Bremer EG, Hooker B, Kawasaki $T$, et al. High mannose glycans and sialic acid on gp120 regulate binding of mannose-binding lectin (MBL) to HIV type 1. AIDS Res Hum Retroviruses 2002; 18:1311-1317.
39. Marzi A, Mitchell DA, Chaipan C, Fisch T, Doms RW, Carrington $\mathrm{M}$, et al. Modulation of HIV and SIV neutralization sensitivity by DC-SIGN and mannose-binding lectin. Virology 2007; 368:322-330.

40. Catano G, Agan BK, Kulkarni H, Telles V, Marconi VC, Dolan $\mathrm{MJ}$, et al. Independent effects of genetic variations in mannosebinding lectin influence the course of HIV disease: the advantage of heterozygosity for coding mutations. I Infect Dis 2008; 198:72-80.

41. Garcia-Laorden MI, Pena MJ, Caminero JA, Garcia-Saavedra A, Campos-Herrero MI, Caballero A, et al. Influence of mannosebinding lectin on HIV infection and tuberculosis in a WesternEuropean population. Mol Immunol 2006; 43:2143-2150.

42. Malik S, Arias M, Di Flumeri C, Garcia LF, Schurr E. Absence of association between mannose-binding lectin gene polymorphisms and HIV-1 infection in a Colombian population. Immunogenetics 2003; 55:49-52.

43. Dzwonek A, Novelli V, Bajaj-Elliott M, Turner M, Clapson M Klein N. Mannose-binding lectin in susceptibility and progression of HIV-1 infection in children. Antivir Ther 2006; 11:499 505.

44. Garred P, Madsen HO, Balslev U, Hofmann B, Pedersen C, Gerstoft J, et al. Susceptibility to HIV infection and progression of AIDS in relation to variant alleles of mannose-binding lectin. Lancet 1997; 349:236-240.

45. Mangano A, Rocco C, Marino SM, Mecikovsky D, Genre F, Aulicino $P$, et al. Detrimental effects of mannose-binding lectin (MBL2) promoter genotype XA/XA on HIV-1 vertical transmission and AIDS progression. I Infect Dis 2008; 198:694-700.

46. Singh KK, Lieser A, Ruan PK, Fenton T, Spector SA. An agedependent association of mannose-binding lectin-2 genetic variants on HIV-1-related disease in children. J Allergy Clin Immunol 2008; 122:173-180; 180 e171-172.

47. Tan $Y$, Liu L, Luo $P$, Wang A, Jia $T$, Shen $X$, et al. Association between mannose-binding lectin and HIV infection and progression in a Chinese population. Mol Immunol 2009; 47:632638.

48. Larsen F, Madsen HO, Sim RB, Koch C, Garred P. Diseaseassociated mutations in human mannose-binding lectin compromise oligomerization and activity of the final protein. / Biol Chem 2004; 279:21302-21311.

49. Terai I, Kobayashi K, Matsushita M, Miyakawa H, Mafune N, Kikuta $\mathrm{H}$. Relationship between gene polymorphisms of mannose-binding lectin (MBL) and two molecular forms of MBL. Eur J Immunol 2003; 33:2755-2763.

50. Amoroso A, Berrino M, Boniotto M, Crovella S, Palomba E, Scarlatti G, et al. Polymorphism at codon 54 of mannosebinding protein gene influences AIDS progression but not HIV infection in exposed children. AIDS 1999; 13:863-864.

51. Garred P, Richter C, Andersen AB, Madsen HO, Mtoni I, Svejgaard A, et al. Mannan-binding lectin in the sub-Saharan HIV and tuberculosis epidemics. Scand I Immuno/ 1997; 46:204 208.

52. Boldt AB, Culpi L, Tsuneto LT, de Souza IR, Kun JF, Petzl-Erler ML. Diversity of the MBL2 gene in various Brazilian populations and the case of selection at the mannose-binding lectin locus. Hum Immunol 2006; 67:722-734.

53. Mombo LE, Lu CY, Ossari S, Bedjabaga I, Sica L, Krishnamoorthy R, et al. Mannose-binding lectin alleles in sub-Saharan Africans and relation with susceptibility to infections. Genes Immun 2003; 4:362-367.

54. Kuhn L, Coutsoudis A, Trabattoni D, Archary D, Rossi T, Segat L, et al. Synergy between mannose-binding lectin gene polymorphisms and supplementation with vitamin $A$ influences susceptibility to HIV infection in infants born to HIV-positive mothers. Am J Clin Nutr 2006; 84:610-615.

55. Garred P, Harboe M, Oettinger T, Koch C, Svejgaard A. Dual role of mannan-binding protein in infections: another case of heterosis? Eur I Immunogenet 1994; 21:125-131.

56. Santos IK, Costa $\mathrm{CH}$, Krieger H, Feitosa MF, Zurakowski D, Fardin B, et al. Mannan-binding lectin enhances susceptibility to visceral leishmaniasis. Infect Immun 2001; 69:5212-5215.

57. Alagarasu K, Selvaraj P, Swaminathan S, Raghavan S, Narendran G, Narayanan PR. Mannose binding lectin gene variants and susceptibility to tuberculosis in HIV-1 infected patients of South India. Tuberculosis (Edinb) 2007; 87:535-543. 